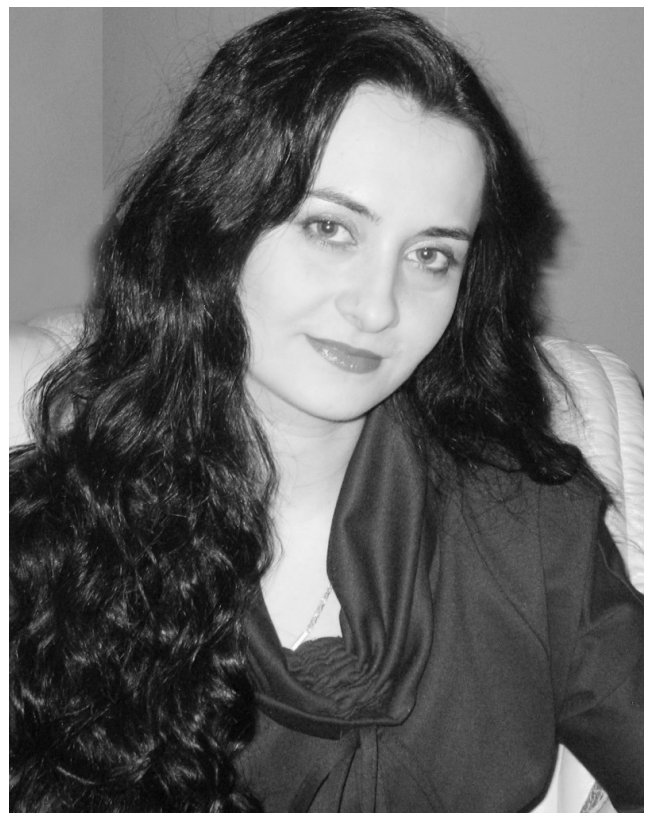

yana.melnik82@gmail.com
UDC: 331.5:330.3

DOI: https://doi.org/10.32689/2617-

2224-2019-4(19)-166-177

Качан (Мельник) Яна Віталіївна, кандидат наук з державного управління, дочент кафедри публічного управління та адміністрування, Інститут підготовки кадрів державної служби зайнятості України, 03038, м. Київ, вул. Нововокзальна, 17, тел.: (044) 53614 85, e-mail:yana.melnik82@gmail.com

ORCID: 0000-0002-4078-7747

Качан (Мельник) Яна Витальевна, кандидат наук по государственному управлению, дочент кафедры публичного управления и администрирования, Институт подготовки кадров государственной службы занятости Украины, 03038, г. Киев, ул. Нововокзальная, 17, тел.: (044) 53614 85, e-mail:

ORCID: 0000-0002-4078-7747

Kachan (Melnyk) Yana Vitalievna, Ph.D. in Public Administration, Associate Professor of the Department of Public Administration and management, Institute for Personnel Training of the State Employment Service of Ukraine, 03038, Kyiv, Str. Novovokzalna, 17, tel.: (044) 53614 85, e-mail:yana.melnik82@gmail.com

ORCID: 0000-0002-4078-7747

\title{
ПРОФЕСІЙНЕ НАВЧАННЯ ТА ПРОФЕСІЙНИЙ РОЗВИТОК ЯК СКЛАДОВІ ДЕРЖАВНОї КАДРОВОЇ ПОЛІТИКИ УКРАЇНИ
}

Анотація. 3’ясовано особливості професійного навчання та професійного розвитку як складових державної кадрової політики України. Доведено, що професійне зростання - це освоєння професії у всій їі повноті й різноманітності, приріст професійних знань, умінь і навичок, що приводить, звичайно, до визнання результатів праці професійним співтовариством, придбання авторитету в конкретному виді професійної діяльності. Визначено, що підвищення якості управління та ефективності діяльності органів виконавчої влади потребує підготовки, перепідготовки та підвищення кваліфікації державних службовців з метою здобуття і поглиблення управлінських, фінансово-економічних, соціальних, правових знань, а також удосконалення професійних 
знань і умінь, здобуття нової спеціальності або кваліфікації на основі раніше здобутої освіти і досвіду практичної роботи. Тому професіоналізація державної служби розглядається як одне з першочергових завдань, без вирішення якого неможливо зробити реальним входження України до спільноти провідних Європейських держав. Доведено, що основними напрямами професійної підготовки мають бути: забезпечення випереджаючого характеру навчання з урахуванням перспектив розвитку держави, удосконалення завдань і функцій органів державної влади; запровадження цільової спрямованості навчання на основі дотримання державних освітніх стандартів, гнучкості застосування усіх видів, форм і методів навчання, досягнення інтенсифікації та оптимізації навчального процесу; вдосконалення підготовки та підвищення кваліфікації кадрового резерву та новопризначених державних службовців; розширення підготовки та перепідготовки державних службовців за спеціальністю “Державна служба” та за спеціалізаціями з економіки, права, а також соціальної, гуманітарної та кадрової політики; оптимізація мережі навчальних закладів різних форм власності, які здійснюють підготовку спеціалістів для державної служби; запровадження дистанційного навчання, що дасть можливість розширити коло державних службовців, які професійно підвищують кваліфікацію без відриву від роботи; забезпечення єдиного навчально-методичного управління та координація практичної діяльності всіх структурних елементів системи. Виявлено, що необхідною умовою ефективного державного управління є його професіоналізація. Важливим інститутом професіоналізації державного управління є система фахового професійного навчання державних службовців шляхом підготовки, перепідготовки та підвищення кваліфікації з використанням нових форм і методів навчання, освітніх механізмів і технологій з урахуванням досвіду розвинених країн світу.

Ключові слова: державне управління, кадрова політика, навчання, професійний розвиток, публічна служба.

\section{ПРОФЕСИОНАЛЬНОЕ ОБУЧЕНИЕ И ПРОФЕСИОНАЛЬНОЕ РАЗВИТИЕ КАК СОСТАВЛЯЮЩИЕ ГОСУДАРСТВЕННОЙ КАДРОВОЙ ПОЛИТИКИ УКРАИНЫ}

Аннотация. Выяснены особенности профессионального обучения и профессионального развития как составляющих государственной кадровой политики Украины. Доказано, что профессиональный рост - это освоение профессии во всей ее полноте и разнообразии, прирост профессиональных знаний, умений и навыков приводит, как правило, к признанию результатов труда профессиональным сообществом, приобретение авторитета в конкретном виде профессиональной деятельности. Определено, что повышение качества управления и эффективности деятельности органов исполнительной власти требует подготовки, переподготовки и повышения квалификации государственных служащих с целью получения и углубления управленческих, финансово-экономических, социальных, правовых знаний, а также совершенствование профессиональных знаний и умений, получение новой 
специальности или квалификации на основе ранее полученного образования и опыта практической работы. Поэтому профессионализация государственной службы рассматривается как одна из первоочередных задач, без решения которого невозможно сделать реальным вхождение Украины в сообщество ведущих Европейских государств. Доказано, что основными направлениями профессиональной подготовки должны быть: обеспечение опережающего характера обучения с учетом перспектив развития государства, совершенствование задач и функций органов государственной власти; введение целевой направленности обучения на основе соблюдения государственных образовательных стандартов, гибкости применения всех видов, форм и методов обучения, достижения интенсификации и оптимизации учебного процесса; совершенствование подготовки и повышение квалификации кадрового резерва и вновь государственных служащих; расширение подготовки и переподготовки государственных служащих по специальности "Государственная служба” и по специализациям по экономике, праву, а также социальной, гуманитарной и кадровой политике; оптимизация сети учебных заведений различных форм собственности, осуществляющих подготовку специалистов для государственной службы; введение дистанционного обучения, что позволит расширить круг государственных служащих, профессионально повысит квалификацию без отрыва от работы; обеспечение единого учебно-методического управления и координация практической деятельности всех структурных элементов системы. Выявлено, что необходимым условием эффективного государственного управления является его профессионализация. Важным институтом профессионализации государственного управления является система профессионального обучения государственных служащих путем подготовки, переподготовки и повышения квалификации с использованием новых форм и методов обучения, образовательных механизмов и технологий с учетом опыта развитых стран мира.

Ключевые слова: государственное управление, кадровая политика, обучение, развитие, публичная служба.

\section{PROFESSIONAL EDUCATION AND PROFESSIONAL DEVELOPMENT AS THE COMPOSITION OF THE STATE PERSONNEL POLICY OF UKRAINE}

Abstract. The article clarifies the peculiarities of vocational training and professional development as components of the state personnel policy of Ukraine. It is proved that professional growth is the development of the profession in its entirety and variety, the growth of professional knowledge, abilities and skills, which leads, as a rule, to the recognition of the work results of by the professional community, the acquisition of authority in a particular kind of professional activity.

It has been determined that improvement of the management quality and efficiency of executive bodies' activity requires the training, retraining and qualification improvement of civil servants in order to obtain and deepen administrative, financial and economic, social and legal knowledge, as well as to 
improveprofessionalknowledgeand skills, obtaininganewspecialtyorqualification. based on previously gained education and practical experience. Therefore, the civil service professionalization is considered to be one of the priority tasks, without which it is impossible for Ukraine to integrate into the leading European states community. It is proved that the main areas of professional training should be as follows: providing a proactive character of training takingintoaccount the prospects of the state development, improvement of tasks and functions of state authorities; introduction of the target orientation of education on the basis of observance of state educational standards, flexibility of all types of application, forms and methods of training, achievement of intensification and optimization of educational process; improvement of training and qualification improvement of the personnel reserve and newly appointed civil servants; expansion of training and retraining of civil servants in the specialty "Public service" and specialization in economics, law, as well as social, humanitarian and personnel policies; optimization of the network of educational institutions of different forms of ownership, which trains specialists for the civil service; introduction of distance learning, which will enable the expansion of the range of civil servants who professionally improve their qualifications uninterruptedly; providing a unified teaching and methodological management and coordinating the practical activities of all structural elements of the system. the introduction of distance learning, which will enable the expansion of the range of civil servants who professionally improve their qualifications uninterruptedly; providing a unified educational and methodological management and coordinating the practical activities of all structural elements of the system. It is revealed that the necessary condition for effective public administration is its professionalization. An important institution for the professionalisation of public administration is the system of vocational training of civil servants through training, retraining and advanced training using new forms and methods of training, educational mechanisms and technologies, taking into account the experience of developed countries of the world.

Keywords: public administration, personnel policy, training, professional development, public service.

Постановка проблеми. Система державного управління в Україні пройшла тривалий і складний період становлення, що супроводжувався постійним реформуванням інституту державної служби і трансформацією принципів і підходів до кадрового забезпечення. Дані принципи знаходять своє відображення в державній кадровій політиці, а їх реалізація в кінцевому підсумку призводить до якісних змін в кадровому складі органів державного управління.

Однак аналіз численних публікацій, присвячених вивченню державної кадрової політики з історичних, політологічних, соціологічних, правових позицій виявляє множинність поглядів, підходів до оцінки її стану та ефективності. 
Аналіз останніх досліджень i публікацій. Питання професійного навчання та розвитку цікавили багатьох провідних науковців, серед яких: Оболенський О., Олуйко В., Скорик В. та ін. Проте, це питання потребує додаткового вивчення, особливо в аспекті дослідження професійного навчання та професійного розвитку як складових державної кадрової політики України, що зумовило вибір теми даної статті.

Мета статті - з'ясувати особливості професійного навчання та професійного розвитку як складових державної кадрової політики України.

Виклад основного матеріалу дослідження. Становлення демократичної, правової держави, розвиток засад громадянського суспільства, європейська інтеграція України, проведення адміністративної реформи вимагають, щоб такі чинники, як професіоналізм, компетентність відігравали провідну роль в діяльності органів державної влади. Потреба посилити ефективність державного управління, зробити його відкритим і прозорим для суспільства є актуальною для сучасної України. Вона вимагає нових підходів до вирішення проблеми кадрового забезпечення органів публічної влади кваліфікованими фахівцями. Сучасна державна кадрова політика країни зорієнтована на професіоналізм та утвердження норм демократичного громадянського суспільства має стати ефективним інструментом розбудови всіх сфер його життя. Проте аналіз існуючої ситуації засвідчує, що сучасний стан кадрового потенціалу органів влади та кадрової роботи не відповідає вимогам часу.
Зокрема, це стосується підготовки, перепідготовки та підвищення кваліфікації кадрів. До того ж, чинна нормативно-правова база не повною мірою дає змогу розробити систему безперервного навчання державних службовців.

Професійне зростання - це освоєння професії, набуття професійних знань, умінь і навичок, що приводить, зазвичай, до визнання результатів праці професійним співтовариством, придбання авторитету в конкретному виді професійної діяльності. Занурення в вузькоспрямовану діяльність дає можливість людині стати унікальним професіоналом і бути затребуваним у своїй сфері діяльності, виступати експертом і т. п. Для просування по щаблях службової ієрархії необхідно розвивати нові компетенції, які не були задіяні раніше. Службово-посадове просування (кар'єра в типовому розумінні) - це розширення відповідальності і повноважень, рух вгору, перехід з одного рівня на інший.

Тому проблема забезпечення органів державної влади якісним кадровим складом управлінців вимагає термінового розгляду на всіх рівнях територіального та галузевого управління. Це і є основним завданням реформування професійного навчання державних службовців.

Досвід утворення і зміцнення Української держави свідчить про значні здобутки у сфері державотворення та формування управлінського персоналу.

За історично незначний термін часу створено владні інституції i запроваджено нові демократичні процедури їх функціонування, роз- 
роблено власну правову систему та сформовано стійке розуміння переваг життя в незалежній державі. Наші досягнення стали можливі завдяки створенню дієвої системи державного управління та наповнення іiі професійно-компетентним кадровим складом державних службовців.

У сучасному змінному світі проблема підготовки фахівців для публічної сфери є найактуальнішою 3 точки зору забезпечення стабільного розвитку суспільства та країни.

Навчання державних службовців повинно мати випереджувальний характер та бути спрямованим на розкриття кадрового потенціалу державного службовця.

У цьому ж руслі висловлює свою думку О. Оболенський, який наголошує, що суспільство і держава потребують підготовки нової генерації і підвищення кваліфікації вже працюючих керівників і фахівців органів державної влади та місцевого самоврядування, тому одним з пріоритетних напрямів соціально-економічного розвитку України має стати якісне удосконалення системи підготовки та підвищення кваліфікації державних службовців [1].

Державна служба нині вимагає професіоналів, людей, які можуть зробити життя суспільства кращим, дивляться на державні справи далекоглядно, стратегічно, прогнозовано.

Державно-управлінські кадри потребують постійної і потужної навчально-професійної підтримки, оскільки, за свідченням статистики, державне управління є високоінтелектуальним видом діяльності, дещо поступаючись за часткою працівни- ків 3 повною вищою освітою лише сфері досліджень і розробок.

Підвищення якості управління та ефективності діяльності органів виконавчої влади потребує підготовки, перепідготовки та підвищення кваліфікації державних службовців з метою здобуття і поглиблення управлінських, фінансово-економічних, соціальних, правових знань, а також удосконалення професійних знань і умінь, здобуття нової спеціальності або кваліфікації на основі раніше здобутої освіти і досвіду практичної роботи. Тому професіоналізація державної служби розглядається як одне 3 першочергових завдань, без вирішення якого неможливо зробити реальним входження України до спільноти провідних Європейських держав.

На сучасному етапі важливо, щоб кожен державний службовець, кожна посадова особа володіли знаннями та уміннями, необхідними для роботи в непростих соціальних, економічних і політичних умовах сучасної України. Розвиток новітніх технологій, науково-технічного прогресу загалом стали причиною великих змін у трудовій діяльності працівників державних установ і організацій, зумовили підвищення вимог до їх професійно-кваліфікаційного рівня.

Структура підготовки, перепідготовки та підвищення кваліфікації державних службовців має забезпечити безперервність і обов'язковість навчання всіх службовців за умови iï органічного зв'язку з професійним розвитком персоналу, плануванням i реалізацією кар'єри, професійними досягненнями, просуванням службовими сходами, присвоєнням чер- 
гового рангу, врахуванням особистих інтересів працівника.

Важливо створити такі умови, за яких і держава, і кожний ㄲï службовець були б взаємозацікавлені у професійному розвитку всього персоналу державної служби і конкретного працівника, у підвищенні ефективності управлінської праці.

У процесі професійного навчання державних службовців особливої уваги потребує їх підготовка до управлінської діяльності.

Основними напрямами професійної підготовки мають бути [2]:

- забезпечення випереджаючого характеру навчання з урахуванням перспектив розвитку держави, вдосконалення завдань і функцій органів державної влади;

- запровадження цільової спрямованості навчання на основі дотримання державних освітніх стандартів, гнучкості застосування всіх видів, форм і методів навчання, досягнення інтенсифікаціі та оптимізації навчального процесу;

- удосконалення підготовки та підвищення кваліфікаціiі кадрового резерву та новопризначених державних службовців;

- розширення підготовки та перепідготовки державних службовців за спеціальністю “Державна служба” та за спеціалізаціями з економіки, права, а також соціальної, гуманітарної та кадрової політики;

- оптимізація мережі навчальних закладів різних форм власності, які здійснюють підготовку спеціалістів для державної служби;

- запровадження дистанційного навчання, що дасть можливість розширити коло державних службовців, які професійно підвищують кваліфікацію без відриву від виробництва;

- забезпечення єдиного навчально-методичного управління та координація практичної діяльності всіх структурних елементів системи.

Підвищення кваліфікації державного службовця - складний організаційний процес, який включає проведення кадрового аналізу та визначення кількісної і якісної потреби в навчанні кадрів, забезпечення навчального процесу змістом і методикою, економічність та ефективність результатів підготовки, перепідготовки та підвищення кваліфікацї.

Для виконання своїх професійних обов'язків державний службовець повинен мати не тільки вузькопрофільні знання, але й бути високопрофесійним, компетентним, здатним визначити найбільш ефективні способи і методи реалізації поставлених завдань у межах нормативно визначених повноважень, вмінням аналізувати та прогнозувати розвиток ситуацій, приймати виважені управлінські рішення.

Одним з найважливіших критеріїв ознак фахівців різних спеціальних підготовок був і залишається рівень іхнього професіоналізму. На думку В. Олуйка, професійний розвиток державних службовців слід здійснювати у двох напрямах: професійно-кваліфікаційному і професійно-посадовому [3].

Процес професійно-кваліфікаційного розвитку на основі навчання і підвищення кваліфікації кадрів повинен базуватися на наступних засадах і принципах.

Обов’язковість - передбачає, що державні службовці підвищують 
свою кваліфікацію постійно, у тому числі через навчання у відповідних навчальних закладах, не рідше одного разу на п’ять років. Обов'язковість підвищення кваліфікації для кожного державного службовця випливає з базового принципу державної служби - професіоналізму. Обсяг і рівень знань мають забезпечувати державним службовцям якісне виконання поставлених завдань, службових обов'язків на рівні сучасних вимог, які постійно зростають. Щоб їм відповідати, кожний державний службовець зобов'язаний постійно вчитися, поповнювати, оновлювати й поглиблювати свої знання, вдосконалювати вміння й навички.

Принцип професіоналізму державних службовців є провідною засадою при організації i функціонуванні державної служби. Це не тільки одна з основних вимог, що визначає формування та практичну діяльність персоналу, але й необхідна правова умова, без якої неможливе отримання права на здійснення посадових повноважень.

Плановість - базується на систематичному аналізі складу державних службовців і вивченні потреб державних органів та їх фахівців у навчанні і передбачає розроблення, погодження та затвердження планів-графіків підвищення кваліфікації державних службовців у відповідних структурах на черговий навчальний рік.

Диференційований підхід - державні службовці - це працівники, які належать до різних професійних груп, виконують різноманітні функції в системі державного управління. Підвищення їхньої кваліфікації має будуватися так, щоб до навчальних потоків, груп зараховувалися працівники, що виконують однакові або близькі функції в органах державного управління. Під час організації i методичного забезпечення навчальних та інформаційних процесів потрібно цілеспрямовано враховувати необхідність формування рівнів знань фахівців різної кваліфікаціі”.

Неперервність, наступність та інноваційність - здобуття знань службовцем слід розглядати як безперервний процес, а не як кінцевий результат певного періоду його життя. Адже, як свідчить практика, ці знання з часом старіють. Працівник, який систематично не підвищує професійний рівень, не збагачує знання, працюе менш ефективно, бо використовує застарілі ідеї, методи, засоби роботи.

Тому керівники державних органів, іх структурних підрозділів мають постійно піклуватися про систематичне підвищення рівня знань державних службовців, їх компетентності.

Забезпечення гуманістичного, демократичного підходу - принцип, що вимагає підтримки й розвитку інтелектуального й морального потенціалу працівників, всебічної демократизації навчального процесу за їхньої активної участі.

Необхідність гуманістичного підходу визначається й вимогами чинного законодавства України до етики поведінки державного службовця. Етика займає важливе місце в управлінні. Прерогативою реформування державно-управлінських структур є створення нової моделі управлінської культури. 
Нерозривний зв’язок теорії 3 практичною діяльністю органів виконавчої влади - враховуючи, що державні службовці представляють державні органи серед громадян України, що за їхніми діями, компетентністю, цілеспрямованістю люди судять про роботу цих органів і держави в цілому. Важливо підвищити роль теоретико-ідеологічної сторони їньього навчання.

Вітчизняний та зарубіжний досвід визначення змісту та організації навчання. 3 одного боку, не слід ігнорувати вітчизняний досвід роботи 3 кадрами взагалі і досвід підвищення їхньої кваліфікації зокрема, вироблений за попередні роки державними органами та різними ланками системи підвищення кваліфікації. Все краще, ефективне з минулого досвіду доцільно з урахуванням сучасних умов i реальних можливостей брати на озброєння і застосовувати в роботі.

Важко переоцінити роль досвіду зарубіжних країн з розвиненими системами державної служби. Заслуговують на особливу увагу практика диференційного підходу до організації підвищення кваліфікації державних службовців, його програмного забезпечення, проведення дистанційного навчання; методика навчання дорослих слухачів, застосування технічних засобів; посилення мотивації державних службовців до підвищення кваліфікації.

Підготовка державних службовців - це здобуття освіти відповідного освітньо-кваліфікаційного рівня спеціаліста, магістра за спеціальностями, спрямованими на професійну діяльність на державній службі, а також навчання в аспірантурі, докторантурі Української Академї державного управління при Президентові України, інших навчальних закладах або наукових установах.

Перепідготовка державних службовців - це здобуття освіти за відповідним освітньо-кваліфікаційним рівнем спеціаліст, магістр 3 іншою спеціальністю в межах відповідної галузі знань.

Підвищення кваліфікації державних службовців - це оновлення та розвиток умінь і знань, необхідних для ефективного вирішення завдань професійної діяльності на державній службі. Основними видами підвищення кваліфікації державних службовців, що забезпечують його безперервність, є: навчання за професійними програмами; систематичне самостійне навчання (самоосвіта); тематичні постійно діючі та короткотермінові семінари; стажування в органах, а також за кордоном.

Професійне навчання має цілеспрямовано формувати здатність державних службовців до інноваційної діяльності, що включає нормативно-проектну, аналітичну, організаційно-розпорядчу, консультативно-дорадчу та контрольну функції.

Становлення системи безперервного професійного навчання державних службовців стало нагальною потребою та одним із важливіших факторів зміцнення державності та становлення соціально-орієнтованої ринкової економіки [4].

Рух України до європейської спільноти вимагає створення системи державного управління та державної служби, орієнтованої на запровадження стандартів реаль- 
ної демократії, похідними яких є демократичні інституційні стандарти професійної діяльності службовців. Реформування державної служби передбачає необхідність визначення та запровадження стандартів професійної діяльності державних службовців на засадах стратегічного планування діяльності державних органів із запровадженням результативного та ефективного обслуговування потреб населення, фізичних і юридичних осіб. Саме зазначені стандарти $є$ базою надання якісних публічних послуг, проходження служби, а також формування та оновлення змісту професійного навчання.

Удосконалення та ефективність діяльності системи професійного навчання може бути досягнута за умови відповідності професійної підготовки та післядипломної освіти вимогам освіти для суспільства, побудованого на знаннях та інформації, а саме:

- освіта протягом усього життя;

- освіта без кордонів, що грунтується на інформаційно-комп'ютерних технологіях і доповнює традиційні методи і технології новими можливостями;

- освіта за креативними моделями навчання та індивідуальними освітніми траєкторіями;

- освіта, що розвивається на основі фундаментальних знань.

Наука не може бути відокремлена від професійної підготовки та післядипломної освіти. Це єдиний комплекс формування інтелектуального капіталу державного управління та місцевого самоврядування.

Необхідно забезпечити прикладний характер магістерської підго- товки, післядипломної освіти та наукових досліджень, диференціацію професійного навчання державних службовців залежно від характеру їх професійної діяльності, потреб органу та держслужбовця.

Забезпечення якості змісту навчання потребує:

- впровадження системи вивчення потреб у підвищенні кваліфікації з урахуванням видів підвищення кваліфікації і категорій слухачів;

- забезпечення практичного характеру змісту навчання шляхом його спрямованості на підготовку слухачів до ефективного виконання посадових завдань.

Отримання професійної освіти має гарантувати позитивну зміну статусу державного службовця. Вважати при цьому навчання в магістратурі передбаченою формою чергового (раз на п'ять років) підвищення кваліфікації.

Оскільки успішна реалізація змісту навчання визначається професіоналізмом осіб, які беруть участь у здійсненні навчального процесу, необхідно систематично підвищувати кваліфікацію професорсько-викладацького складу магістратур публічної служби шляхом стажування в центральних та місцевих органах влади.

Ефективне вирішення цієї проблеми може бути забезпечене шляхом використання технологій дистанційного навчання в телекомунікаційній мережі державної служби. Дистанційне навчання дає можливість адаптуватися до базового рівня знань і конкретних цілей навчання кожного індивідуума, залучати кваліфікованих спеціалістів 
(що неможливо при інших умовах), забезпечити доступ до учбового матеріалу у зручний для користувача час, його дистанційну участь в телесемінарах і кваліфіковану допомогу викладача. Крім традиційних засобів заочного навчання (розсилка інформаційних матеріалів і завдань) i організації навчання за допомогою курсів, дистанційне навчання дає змогу організувати ділові ігри, дискусії, телеконференції, що значно підвищує якість придбаних знань та здатність спеціаліста, який навчається, до самостійних і своєчасних рішень і дій.

Запровадження у систему підготовки, перепідготовки та підвищення кваліфікації державних службовців та посадових осіб місцевого самоврядування дистанційного навчання, i, особливо, започаткованого на методах інформативно-комунікативних технологій, дасть змогу не тільки охопити навчанням максимально можливу кількість слухачів та підвищити їхній професійний рівень, а й через залучення до високих технологій передавання інформації адаптувати їх до нових умов розвитку “інформаційної цивілізації”, іï розуміння і сприйняття.

Таким чином, ефективне функціонування системи професійного навчання працівників органів державної влади, іiі наукове, навчально-методичне, матеріально-технічне вдосконалення, ефективність кадрової політики на регіональному рівні прямо залежать від застосування інноваційних моделей освітніх закладів, пошуку та утвердження нових форм професійного навчання управлінських кадрів.
Отже, необхідною умовою ефективного державного управління $€$ його професіоналізація. Важливим інститутом професіоналізації державного управління є система фахового професійного навчання державних службовців шляхом підготовки, перепідготовки та підвищення кваліфікації з використанням нових форм і методів навчання, освітніх механізмів і технологій з урахуванням досвіду розвинених країн світу. Такий підхід дасть змогу якісно підійти до забезпечення державної кадрової політики та створить умови для послідовного оновлення персоналу державної служби України.

Висновки та перспективи подальших досліджень. Таким чином, осмислення сучасного розуміння професійного розвитку дозволяє розглядати навчання як його неодмінну умову, а кар'єрне зростання як можливий і необхідний результат. Отже, провідною тенденцією у становленні принципу професійного розвитку в державній кадровій політиці є вимога постійного підвищення професіоналізму кадрового складу шляхом професійного розвитку державних службовців, при цьому завдання розвитку професійних якостей змінилося установкою на розвиток професійних компетенцій $\mathrm{i}$ підвищення професійної компетентності.

Одним із стратегічних завдань державної кадрової політики на сучасному етапі є формування високопрофесійного складу кадрів публічної служби. Реалізація даного завдання повинна приводити до якісних змін в кадровому складі державних органів. 


\section{СПИСОК ВИКОРИСТАНИХ} ДЖЕРЕЛ

1. Оболенський О. Ю. Державна служба України: реалізація системних поглядів щодо організації та функціонування: монографія. Хмельницький: Поділля, 1998. С. 227.

2. Скорик В. О. Основні напрями реформування Державної служби України / В. О. Скорик // Митна справа. 2014. № 2(2.1). С. 150155.

3. Олуйко В. М. Кадри в регіоні України: становлення та розвиток / В. М. Олуйко. К.: Науковий світ, 2001. C. 136.

4. Оболенський О. Ю. Розвиток магістерських програм публічного адміністрування в Україні // Вісн. держ. служби України. 2007. № 4.

\section{REFERENCES}

1. Obolenskyi O. Yu. (1998) Derzhavna sluzhba Ukrainy: realizatsiia system- nykh pohliadiv shchodo orhanizatsii ta funktsionuvannia [State Service of Ukraine: Implementation of systemic views on organization and functioning]. Monograph. - Khmelnytsky: Podillya. 227 [in Ukrainian].

2. Skoryk V. O. (2014) Osnovni napriamy reformuvannia Derzhavnoi sluzhby Ukrainy [The main directions of the reform of the State Service of Ukraine]. Mytna sprava - Customs business. 2(2.1), 150-155 [in Ukrainian].

3. Oluiko V. M. (2001) Kadry v rehioni Ukrainy: stanovlennia ta rozvytok [Personnel in the region of Ukraine: formation and development]. Kyiv: Naukovyi svit, 136. [in Ukrainian].

4. Obolenskyi O. Yu. (2007) Rozvytok mahisterskykh prohram publichnoho administruvannia v Ukraini [Development of master's programs of public administration in Ukraine]. Visnyk derzhavnoi sluzhby Ukrainy - Bulletin of the Civil Service of Ukraine.4. [in Ukrainian]. 